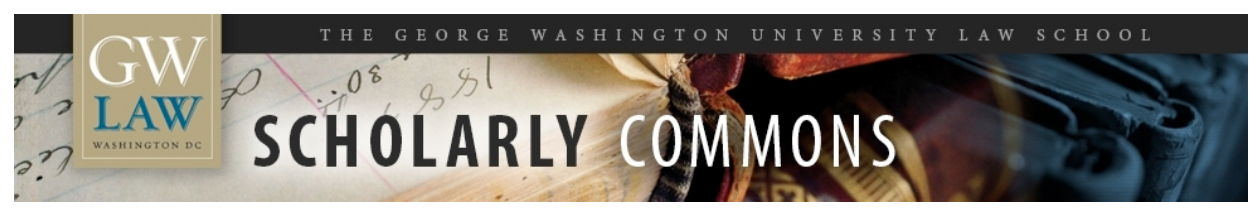

\title{
Brown and the Contemporary Brazilian Struggle Against Racial Inequality: Some Preliminary Comparative Thoughts
}

\author{
Robert J. Cottrol \\ George Washington University Law School, bcottrol@law.gwu.edu
}

Follow this and additional works at: https://scholarship.law.gwu.edu/faculty_publications

Part of the Law Commons

\section{Recommended Citation}

Robert J. Cottrol, Brown and the Contemporary Brazilian Struggle Against Racial Inequality: Some Preliminary Comparative Thoughts, 66 U. Pitt. L. Rev. 113 (2004).

This Article is brought to you for free and open access by the Faculty Scholarship at Scholarly Commons. It has been accepted for inclusion in GW Law Faculty Publications \& Other Works by an authorized administrator of Scholarly Commons. For more information, please contact spagel@law.gwu.edu. 


\title{
BROWN AND THE CONTEMPORARY BRAZILIAN STRUGGLE AGAINST RACLAL INEQUALITY: SOME PRELIMINARY COMPARATIVE THOUGHTS
}

\author{
Rabert J. Cottror ${ }^{*}$
}

We are told by both ancient scripture and popular song that there is a time for every purpose under Heaven.' Last year, 2004, was the occasion to reflect on the fiftieth anniversary of what I would submit was the most important thing the United States Supreme Court has ever done-render its decision in Brown v. Board of Education. ${ }^{2}$ As a nation we have spent the past year doing this, and on the whole I think it should be said doing this rather well. There have been numerous symposia and conferences devoted to the 1954 desegregation decision. There have been panels at academic conferences devoted to the topic. News programs and interviews with surviving participants have already taken place and will likely continue into 2005 , as we contemplate the fiftieth anniversary of Brown $\mathrm{H}^{3}$ The fiftieth anniversary has been the occasion for the publication of a number of books on the case, including one that $I$ have co-authored.' More are sure to follow.

- This article originated as a paper delivered at the symposium Brown v. Board of Education: Commemorate the Tuming Point [Fiftieth Anniversary Symposinu], held at the University of Pituburgh School of Law, Febrary 6, 2004.

*4 Harold Paul Green Research Professor of Law, and Professor of History and Sociology, George Washington University. in this article.

- Editor's Note. The autbor bas certified the eccuracy of the forcign language sources included

1. Eccleslastes 3:1-10 (King James); Pete Seeger, Turn/ Tura/ Tum! (To Everything There is a Season), on If I HAD A HAMMER: Soxos OF Hore \& Struodre (Smithsonian Follways 1998).

2. Brown Y. Bd. of Educ, 347 U.S. 483 (1954) [Brown J].

3. Brown v. Bd. of Educ., 349 U.S. 294 (1955) [Brown II].

4. See, e.g., Dexrick A. BEL, SILENT Covenants: Bromn r. BoAro of EDUCation AND the

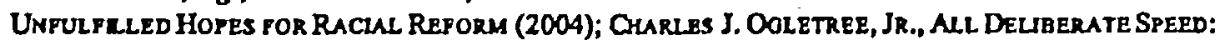
REFlections ON THE FIRST HALF CENTURY OF BROFN V. BOARD OF EOUCATION (2004). The fiftieth anniversary bus occusioned the release of a new edition of Richard Khiger's Simple Justice. See RuCHARD Kluger, Sogre Justre: The History of Brown v. BoArD of EDUCation and Blacx America's Strugolb for Equaltry (2d ed. 2004). See also Micharl J. KLarman, From Jim Crow to CiviL

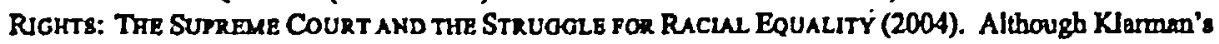
study is broader tban Brown, bo devotes considerable attention to the cese and the struggle for school desegregation more gentrally.

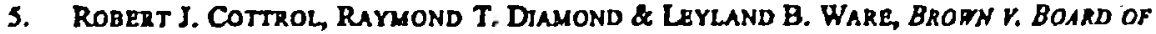
Eovcatjon. CAste, Culture ard the Constmution (Peter Charles Hofier \& N.E.H. Hall eda., 2003). 
The attention that we are paying to Brown in this season of its fiftieth anniversary is entirely appropriate. In perhaps more ways than can be counted, Brown is central to an understanding of the legal and social history of race relations in the United States. Brown cannot be understood apart from an understanding of the role of caste in American history. ${ }^{6}$ The dilemma of caste in a free society was best captured by Thurgood Marshall in his oral argument in Brown. On December 8, 1953,.Marshall stood before the Supreme Court and asked the question that was central to the case, as it was indeed the central contradiction in the whole American chronicle: "Why, of all the multitudinous groups of people in [the United States], you have to single out Negroes and give them this separate treatment?"

The caste system that Marshall was fighting in Brown was older than the Constitution. It was indeed older than the nation itself. It came about in large part because of the very liberal and egalitarian nature of the American experiment. Slavery was a glaring contradiction in a nation whose founding document proclaimed the equality of all men. If there were to be slaves in a nation that proclaimed "that all men are created equal," then slaves, along with the Africans and their Negro descendants from whom the slave population was drawn, would have to be seen as something radically different. They were human beings to be sure - that had been recognized fairly early on, and after the Revolution, the law was actually moving toward a greater recognition of, and protection for, the slave's humanity. But black people could nonetheless still be human beings of a radically different sort, excluded from emerging American notions of the rights of man and the consent of the governed. They were to be slaves, and even the minority that was free was permitted only a conditional quasi-freedom.'

This caste system that would have its origins in American slavery would persist long after emancipation. The Jim Crow ritualistic separation of the races was part of an effort to maintain the system of racial hierarchy that had

6. I bave argued dsewhere, aod would reiterate here, that in many mays fre tem caste is problematic and indeed probably inadequate. The tern caste was borrowed from the social structure found on the Indian subcontinent. Caste, in that system, was presumably rooted in the Hinctu religion and accepted, at least nominally, by that religion's adherents. Much of African-American bistory can be seea as a struggle against the attempt to impose a caste system. See id. at 8-9.

7. Id. at 1.

8. See Thomas D. Morrus, SOUthern Slavery AND the LAW, 1619-1860, 171-81 (Thomas A. Green \& Hendrik Hartog eda, 1996).

9. This was espocially true in the slave states. See generally lRa BERLIN, SLAves WTHOUT Masters: The Free Neoro n tire ANTebeluUm Soutr (1974). 
developed from slavery. ${ }^{10}$ The American caste system had a profound impact on Americans, black and white. It created a culture of race. That culture of race often demanded the exclusion of black people from many of the major, and very often the minor, institutions of American society. It even had a profound influence on the very way we view race. Our notions of who is black and who is white, the idea that any traceable African ancestry, however attenuated, makes an individual black, stems from the historic caste system in. the United States. ${ }^{.1}$

Brown was important, indeed critical, because it would spell the beginning of the end of the law's formal sanctioning of a separate caste system. The American caste system, having been in many ways uniquely a legal creation, had to be attacked, at least initially, with legal tools. Brown was the beginning of the dismantling of the legal support for caste and castelike distinctions. We are all familiar with the major milestones of that postwar struggle, including the Civil Rights Movement, the enactment of the Civil Rights Act of 1964 and the Voting Rights Act of 1965, among others.

We have made tremendous strides in postwar America, strides that would have been impossible to conceive of without Brown. American law has ceased to prescribe caste and inequality as it once did only a very short time ago. This is an underappreciated achievement and I would argue that it is incumbent among those of us who are professional students of American race relations to recognize the depths of this achievement, whether we ultimately remain pessimistic or optimistic concerning race relations in the nation's future.

Still, the end of the legally-mandated caste system has not ended inequality. Americans of African descent face persisting social, economic and educational inequalities and are often burdened by racial stigma. The battle over how to overcome the legacy of caste, discrimination, and, indeed, contemporary disadvantage and stigma, remains as urgent in the first decade of the twenty-first century as it did in the last decade of the twentieth. We are left with a familiar syllabus of questions: Will affirmative action survive into the twenty-first century? Does it stigmatize its beneficiaries and does it benefit the neediest African-Americans, or only those who are already comfortably middle-class? ${ }^{12}$ Should the United States or state govermments or private corporations pay reparations for slavery or systematic

10. COTTROL, DIAMOND \& WARE, supta note 5, at 34-37.

11. See, e.g., Raymond T, Diamond \& Robat J. Cottrol, Codifying Care: Louisiana's Raclal Classification Scheme and the Fourtenth Amendment, 29 LoY. L. Rrv. 255 (1983).

12. See, e.g., Grutter v. Bollinger, 593 U.S. 306, 373 (2003) (Thomas, J., dissenting). 
discrimination after slavery? ${ }^{13}$ Should we retain the notion that any traceable African ancestry makes an individual black, or should we formally recognize a mixed-race category in the census? ${ }^{14}$ Should government even be in the business of racial classification? ${ }^{15}$

This familiar history and our resulting contemporary dilemmas are wellknown to most Americans and certainly to historians, social scientists, and members of the legal academy. It is easy to place Brown and our fiftieth anniversary deliberations on the case within the familiar context of the history of race relations in the United States and the struggle against caste that has characterized that history. Yet, Brown has a significance that is even broader than its pivotal role in the struggle against a legally-sanctioned caste system in American culture. Brown must be seen as part of a larger movement in the postwar World: the struggles against traditional systems of inequality, hierarchy and disadvantage. The struggle against the Nazis and the revulsion toward Nazi racism belped generate new ways of thinking about race in many societies. It certainly helped play a role, if perhaps a hard-to-define role, in the Brown decision itself. ${ }^{16}$ If Brown helped to fuel the postwar civil rights movement in the United States, that civil rights movement was also fueled by the knowledge that similar struggles were occurring in other societies. The relationship was symbiotic - the struggles for human dignity in other societies in turn were fed and continue to be fed by the example of the Civil Rights movement in the United States. The movement against apartheid in South Africa drew inspiration from the fight against Jim Crow in the United States. ${ }^{17}$ The movement for equal rights for Catholics in Northern Ireland saw parallels with the Afro-American fight against American segregation. ${ }^{18}$ India, home of the religiously-based caste system that helped inspire segregation and exclusion in the United States, today is attempting to institute affirmative action programs designed to bring into that society's mainstream people from

13. See, e.g., Alfred Robinson, Corporate Social Responsibllity and African American Reparations: Jubilee, SS RuTOERs L Rev. 309 (2003).

14. See, e.g., Tanya K. Hernandez, "Multinacial" Discourse. Recial Classification in an Era of Colom-Blind Jurisprudence, 57 MD. L. REv. 97, 100-15, 157 (1998).

15. In 2003, a proposed initiative, Proposition 54, probsiting state and local governments in Califoraja from gathering and mintaining racial statistics, was on the ballot. The messure, spansorad by University of Califomia Regent Wand Connerty. and defeated. See Leslie Wolf Branscomio, Defeat of Prop. 54 is Called Win for Grass-Rools Palitics, SAN DigGo Union-Trib., Oct. 8, 2003, at All.

16. CotTrol, Dlamond \& WARE, supra note 5 , at 97.

17. See, e.g., William Schneider, For South Africa, An American Example, LA. Tises, June 30, 1985, Opinion, at 4.

18. Id. 
castes traditionally excluded from positions of power and respect. ${ }^{19}$ This process continues world-wide. In the fall of 2003, I had the privilege of meeting Jack Greenberg, one of the heroes of the Brown litigation effort. He is continuing the struggle against legally-mandated inequality that he began more than half a century ago. Greenberg had just returned from Eastern Europe where he was helping governments in that region dismantle the systems of separate and decidedly unequal schools for Roma children.

We in the legal academy need to take a closer look at the struggle to eradicate caste and inequality as part of a world-wide effort and not simply as a concern peculiar to the United States. The hard questions we are currently asking conceming inequality, the remedies for inequality, and the proper balance between devising ways of bringing members of historically disfavored groups into the mainstream, while recognizing the need for fundamental faimess toward members of historically advantaged groups, are questions that are being posed in nations around the world. Our discussions of policy alternatives and legal remedies need to be informed by parallel dilemmas in other societies.

Among the nations currently struggling with issues of a legacy of discrimination and inequality and how to remedy the exclusions of the past and present is Brazil. It is, I think, entirely appropriate in this season of the half-century commemoration of the Brown decision to note another recent fiftieth anniversary that passed largely unnoticed in the United States. The year 2001 was the fiftieth anniversary of Lei No. 1.390 ("Lei Afonso Arinos"), ${ }^{20}$ Brazil's first national civil rights statute. If this milestone went largely unnoticed in the United States, it was the occasion for no small amount of national selfexamination in Brazil. ${ }^{21}$ The summer of 2001, the fiftieth anniversary of Lei Afonso Arinos, saw mumerous articles in the nation's leading magazines and newspapers devoted to assessing issues of racial discrimination and inequality in the nation. ${ }^{22}$ It also brought into the open what had been an inchoate national debate on affirmative action a way to both combat past and present discrimination in Brazilian life and to overcome structural inequality.

19. For a diccussion of the gap between India's affirmative action policy and the implementation of that policy, see Stephanie Giry, SOL, THE NEw RerubLrc, Apr. 26, 2004, at 12.

20. Lei No. 1.390 de julbo de 1951.

21. See Robert J. Cottrd, The Long Lingering Shadow: Low, Liberalism, and Cuthures of Racial Hlerarchy and Identity in the Americas, 76 TUL. L Rev. 11, 70-73 (2001).

22. See the July 4,2001 edition of the pational news magaine ISTOE which ran a covar story Voce e Raclsta? (Are You Raclst?). 
Brazil's path to this bit of national soul-searching over the issue of race has some interesting parallels and differences with the American odyssey with race and rights. Brazil had a history of African slavery and the enslavement of the descendants of Africans that was longer and more profound than the history of slavery in the United States. Brazilian slavery began before Portugese settlement of the Americas. African slaves toiled in the cities of Portugal and in the sugar plantations of the Azores even before the Columbian voyages to the Americas. ${ }^{23}$ Unlike the English, who had to develop systems of slavery in the Americas, the Portuguese were able to import an alreadyexisting system of slavery to Brazil. More than three million African captives went to the sugar and coffee plantations and mines of Brazil, dwarfing the 500,000 to 600,000 Africans that are estimated to have been brought, enslaved, to what is now the United States. ${ }^{24}$ Slavery was finally abolished in Brazil in 1888, more than a generation after Appomattox and the Thirteenth Amendment. ${ }^{23}$ Today, Brazil has an African-descended population of over fifty million, the second-largest population of African descent in the world after Nigeria. ${ }^{26}$

This is not the occasion to go into an elaborate discussion of slavery and race in Brazil. That topic has been extensively covered in historical and social-science literature elsewhere and is the subject of an important body of scholarship in history and the social sciences. ${ }^{27}$ It is also an ongoing interest of mine, one that $I$ have addressed in a previous law review article. ${ }^{28}$ Unfortunately, it is also an area largely unaddressed in the legal literature in the United States. ${ }^{29}$ It would be accurate to say that for many decades, the

23. See, eg., Frbdertc Mauro, le Portugal, Le Brasi, et L'atlantique au Xvi Stecle (1570-1670): Etude Economique 165-66 (1983); A. C. De C. M. SAunders, A Soclal History of

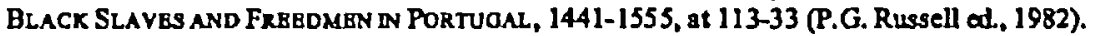

24. Herbert S. Kibn, The Aprican Slavg Trade 210-11 (Stuart Schwartz ed, 1999).

25. For general exemination of the abolition of slavery in Brazil, see RoBert Conrad, ThB

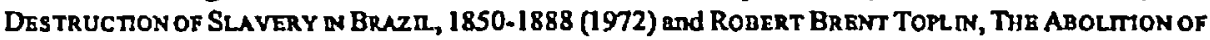
SLAVERY IN BRAZK (1972).

26. Cottrol, supna note 21 , at 14.

27. For a general overview of the field, see Jerry Davila, Expanding Pespectives on Race in Brazil, 35 LATD AM. REs. REY. 188 (2000).

28. Cottrol, supra note 21.

29. Political scientist Sah Racusen has addressed the difficulties in spplyiag Brazilian civil rights law. See Seth Racusen, Mating the "Impassible" Determination: Flaxble Identity and Targeted Opportunity in Brazil, 36 CoNN. L. RBV. 787 (2004). Legal scholar Tanya Hemandea has looked generally at the issue of civil rights bw in Latin America. See Tanya Kateri Heraandez, Comparative Judging of Ctwil Rights; A Transnational Critical Race Theory Appraach, 63 LA. L. RBV. 875 (2003); Tanya Kateri Hernandez, Multinacial Matrix: The Role of Race Ideology in the Eyforcenent of Antidiserimination Lows, A United States-Latin America Companson, 87 CORNE LI L. REV. 1093 (2002); Tanya X.Hlemandex, 
literature on race in Brazil celebrated the notion of Brazil as a "racial democracy." 30 There were many reasons for this, but one reason was, perhaps, more important than the others, particularly for our purposes. Brazil lacked the kind of state-sponsored, legally-mandated system of racial discrimination that prevailed for many years in the United States. ${ }^{31}$ The two American Republics have had similarities in their racial histories-African and AfroAmerican slavery, the virtual continuation or attempt at continuation of the master-slave relation in some regions after formal emancipation, industrial competition between Afro-American populations and later immigrants from Europe and Asia, often-significant regional differences in race relations, and negative stereotyping of people of African descent. ${ }^{32}$ But still, there were significant differences. The United States had a much longer history of erecting formal caste-like barriers between black and white. This had been true even during the long slave era in both societies. If Brazilian slavery was physically harsher than slavery in the United States, Brazil as a slave society was nonetheless more comfortable with its free Negro population and more willing to recognize free Afro-Brazilians as citizens entitled to the rights of other citizens. ${ }^{33}$ The southern states of the United States were largely uncomfortable with their free black population. This discomfort was reflected in the law of the southern states which, particularly in the nineteenth century, increasingly curbed the limited set of rights enjoyed by free AfricanAmericans. ${ }^{34}$

This difference continued after the abolition of slavery. In many ways, the development of Jim Crow in the early twentieth century was a way of preserving the system of racial caste that had been part of the South and the nation's culture in the slave era. ${ }^{3 s}$ Jim Crow required an elaborate legal

An Exploratton of the Eflcacy of Class-Based Approaches to Raclal Justl ce: The Cuban Context, 33 U.C. DAVTS L. Rev. 1135 (2000).

30. Melissa Nobles, Shades of Ctmzzemsha: Racr and the Census in Modern Polmics $106-12(2000)$.

31. Georoe Reti Andrews, Blacxs \& Whites nn SAo PaOLo, Brazd, 1888-1988, at 3-5 (1991) (discussing the importance of state-mandated discrimination in reviewing the differ ences between Brazil, the United Ststes and South Africa). Political scientist Arshony Marx ako disausses the critical role of the state and its legal rystems in constructing systems of racial hierarchy. See ANTHONY W. MARX, MAKINa

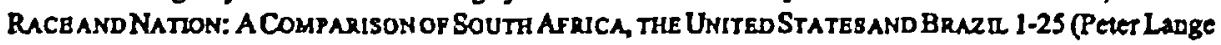
Cd. 1998).

32. See generally ANDXEWS, supra note 31.

33. Cottrol, supra note 21, at 56-57.

34. Id. at 48-52.

35. Id, at 62 . 
regime to classify and prescribe venues for the separation of the races $^{36}$ The school segregation that was finally declared illegal in Brown was but one manifestation of a much larger system of legally-mandated apartheid that existed in the South and other regions of the nation.

By and large, Brazil lacked this history of legal discrimination that characterized American race relations for much of the post-emancipation era. With the principal exception of its immigration laws that favored European immigration, and to varying degrees prohibited the immigration of others, Brazilian law in the twentieth century has lacked the caste-like character of its American counterpart. ${ }^{37}$ This contrast with the patent, legally-mandated system of racial discrimination in the United States contributed to the notion of Brazil as a racial democracy - a harmonious society where blacks, whites, and particularly mulattoes, all interacted and blended together with ease and without discrimination. ${ }^{38}$ It was a view that was encouraged by Brazilian writers, historians, and, particularly after the Second World War, the Brazilian government. ${ }^{39}$

And yet, the image was very much belied by stubborn facts. Brazil has been a nation of often-startling inequalities-inequalities not coincidentally correlated with race. Although Brazilian law has not had a history of mandating discrimination, strong discrimination has nonetheless existed against Afro-Brazilians. For example, the passage of Brazil's first civil rights statute, Lei Afonso Arinos, in 1951, was occasioned by Brazil's international embarrassment over an incident involving discrimination against a visiting black celebrity from the United States. ${ }^{40}$ As early as the 1950 s, social scientists connected with the University of São Paulo were challenging the view that Brazil was a racial democracy by providing detailed research illustrating the extent of racial discrimination and inequality in Brazilian life."t

36. CotrRot, Diamond \& WARE, supra note $S$, at 28-29.

37. Cottrol, supra note 21, at 64-66.

38. Undoubtedly, tho most influential Brazilian champion of the notion that Bravil is a rectal democracy was social historian Oilberto Freyre. Beginning in the 1930s, and continuing for better than ono-balf a century, Freyre's writings celebrated the mixture of races in Brazil and what he argued was the absence of racial conflict in that rociety. See, e.g., GLeERTo FreYaB, THE MANsions AND thB SHANTtBs (Somrados a Mucambos): The Makuno op Modern Brazd (Harriet de Onis trans. \& ed, 1963).

39. NoBLES, supra note 30 , at 91-106

40. Carl N. Deglar, Nether Buack Nor White: Slavery and Race Relateng in Brazla and THE UNITED Statbs 138-39 (1971).

41. The best-known of these bas Brazilian socidogist Florestan Fernandes. See, e.g., FLORESTAN Fernandes, The Nboro nn Brazzlan Society (Jacqueline D. Skiles et al trans, Phyllis B. Eveleth ed., 1969). 
I think it is fair to say that despite the very real persistence of both inequality and discrimination in Brazilian life, an Afro-Brazilian effort to combat these evils remained quite underdeveloped until relatively recently. I think this is certainly so when contrasted with the Civil Rights movement in the United States. Several explanations might be advanced to explain this fact. First, the lack of the kind of clear and formal, indeed legally-required, barriers that existed in the United States gave potential Afro-Brazilian activists less of a clear target. How do you attack a barrier that few are willing to acknowledge even exists? Second, flexible definitions of racial categories and a tendency to "promote" successful Brazilians with African ancestry out of the black category and sometimes out of the mulatto category, have led to a lesser sense of racial cohesion among those who might be categorized as "Afro-Brazilians" than has been the case among those currently categorized as "African-Americans" in the United States. This is what historian Carl Degler once termed "the mulatto escape hatch." ${ }^{\text {M2 }}$ Third, an authoritarian government in Brazil, including a better than twenty-year reign of military government between 1964 and 1985, discouraged protest movements. This curtailed the possibilities of racial protest, including potential A fro-Brazilian protests or civil rights movements. ${ }^{43}$

Here is where Brown, and the movements for civil rights and racial remedy that were partly inspired by that decision, become important to this discussion. The successes of the U.S. civil rights movement helped spur a reassessment of the role of race in Brazilian life. If the pace of racial progress in the United States has at times seemed agonizingly slow to those of us in the United States with personal and professional interests in that progress, the dismantling of traditional racial hierarchies has been even slower in the nations of Latin America, including Brazil. Where once the Jim Crow United States provided a comforting comparison for many who had been invested in the ideology of racial democracy, the contrast with the post-Jim Crow United States was less reassuring." As American law and governmental policies became more positive forces for the elimination of racial barriers in the United States, they raised the question of racial inequality in Brazil in a new light. ${ }^{45}$ By the 1980 s and 1990s, Afro-Latin Civil Rights activists throughout Latin

42. See DeOLER, supra note 40, at 226-32

43. Peggy A. Lovell, Prefádo, in Desioualdade Racial No Brasiz Contbmporaneo 7 (Peggy A. Lovell ed, 1991).

44. See Raca e Classe no Brasll: Perspectiva Histórica, in Desioualoade Racial. No Brasi. COMTEMPORANEO, supra note 43 (Thomas E. Sbidmore's discussion).

45. Id. 
America began looking anew at the question of race in their own societies. Just as the contrast between Jim Crow America and the relatively racially open societies of Latin America had, in the 1930s, 40s, and 50s, caused North American scholars and civil rights advocates to compare race in the United States unfavorably with race in Latin America in the 1990s, advocates of racial progress in Latin America were making unfavorable comparisons between progress made in the United States and the relative lack of progress in their own nations. ${ }^{46}$

This reassessment has been the most advanced in Brazil, the nation with the largest population of African descent in the hemisphere. Despite Lei Afonso Arinos, subsequent civil rights legislation in the intervening halfcentury, and provisions in the 1988 Constitution declaring racism to be a crime (and indeed a crime for which bail is unavailable), Brazilian civil rights activists have been stumed at the persistence of racial inequality in their society. ${ }^{47}$ Disparities in education, wealth, income, and access to healthcare have been well-documented in Brazilian and foreign social-science literature. ${ }^{43}$ The social-science literature has also indicated that racial discrimination plays

46. Undoubtedly, the most importarit a ample of a U.S. schoker whose vision of the differeaces in race relations in Latin America and the Unitod States was rooted in the contrest between Latin America and the Jim Crow United States was Frank Tannenbaum, a sociologist with a special interest in Latin America. Writing in the 1940s, Tannenbaum constructed a comparative legal and social history of race relations in the Americas in an attcopt to answer the question why African-Americans were so scemingly wellintegrated in the societies of Latin America and were segregated and marginalized in the United States. His work has come under intensedy critical serutiny in recent decades, although I think it is fir to say that in many ways his work still sets many of the terms of debate, ar at least is an important point of departure in the fields of comparative shvery and race rebations. See generally FRANK TANNENBaUm, SLAVE AND Ctrzen: The Negro IN THB AmEricas (1946). Historian Akjandro de la Fuente, a specialist in race relations in Cuba, argues that despite modern criticism, much of Tanoenbsum's view remains essentially accurate and useful. See Alejandro de la Fuente, Afyths of Ractal Democracy: Cuba, I900-1912,34 LATw AM. Res. RzV. 39, 43-49 (1999).

47. For a convenient compendium of Brazi lian anti-discrimination legislation see HépIo SILVA JR., Anti-ractsio: Colot Aneas De Las Brastzetras: Federais Estaduaise Municipars (Oliveira Meodes od., 1998).

48. See, eg., Edwand Tdles, Industrialization and Racial hequality in Employment: The Brozilian Example 59 AM. Soc. REV. 46 (1994) (indicating that, in Brazil, industrialization tends to reduce inequality in blue collar occupations, but leaves inequality either untouched or increased in professional occupations); Charles H. Wood \& Peggy A. Lovell, Racial Inequality and Chlld Mortality in Brazt, 70 SoClAL FORCBs 703 (1992) (indicating a significant child mortality gap between whites and Afro-Brazilians even after controlting for such factors as region, incone, and parental education). Seo also Cutos A. Hasenbajg \& Nelson do Valke Silva, Raça e Oporthoidades Educocionais no Brasil, in Desrouradade Ractal No Brasil Contemporanbo 241, 241-62 (Peggy A. Lovel] od, 1991). Hasenbalg, Vice Diroctor and Professor at the Center for Afro-Asinn Studies at the State University of Rio de Janciro, and Silva, a Researcher at Brazil's National Laboratory for Scientific Computing, documented racial inequality in education in Brazil through an analysis of data from the 1980s. Id. 
a significant role in producing these disparities. ${ }^{49}$ The absence of AfroBrazilians in professional positions, in the universities, the foreign ministry, and the senior ranks of the armed forces have also been noted by many observers. $^{50}$

Persisting inequality in the land of "racial democracy" forced a reconsideration of anti-discrimination law in Brazil. Brazil was a pioneer in the passage of anti-discrimination law. If Brazilian law, enshrined in the 1988 Constitution, criminalized racial discrimination and represented a national normative consensus concerning the evils of racism, why did so much in the way of inequality and discrimination still persist? A number of Brazilian legal scholars were beginning to wonder if they might fruitfully study the North American experience, and if civil rights law in the United States might provide some answers.

Inequality in education, particularly higher education, has been one such point of comparison. Brazil has a first-class system of public universities, both state and federal. Students admitted to these universities are entitled to tuition-free educations. Admission to public universities is governed by a stringent admission exam entitled "the vestibular." Although the exams are vigorously defended by their champions as fair and meritocratic, success on the exams is highly correlated with family income. In brief, well-to-do families; whose children have had strong secondary educations in private schools, tend to score higher on vestibular exams and thus receive the benefit of free public universities. Children of poor families, who have had weak public school secondary educations, tend to score lower and are denied the benefit of free public universities. ${ }^{\text {sI }}$ As a disproportionate percentage of the nation's poor, Afro-Brazilians have historically been significantly underrepresented in the nation's public universities. ${ }^{52}$

Throughout the 1990s, Brazilian scholars in law and the social-sciences began looking toward affirmative action as one way of ameliorating the effects of both outright discrimination and the kind of structural inequality represented in university admissions, employment, and other facets of Brazilian life. ${ }^{33}$ Although advocacy of affirmative action was gaining

49. See supra note 48.

50. See Cottrol, supra note 21, at $70 \mathrm{n} .309$ and accompanying text.

51. Id. at 71-73.

52. Id.

53. See, e.g., Açao Affirmattva E Diversmade No Trabalho: Desapios E Possibildoades (Maria Aparecida \& Silva Beato eds, 2000) (a collection of essays that grew out of a 1996 conference held in San Paulo on inequality in the Brazilian workplace). 
momentum in the 1990s, Brazilian law, particularly the Constitution of 1988 , was seen as posing formidable barriers to race-conscious measures as a means of redressing deeply rooted inequalities. ${ }^{34}$

Undoubtedly, one of the more important of the Brazilian legal scholars arguing that affirmative action could be reconciled with the antidiscrimination provisions of the Brazilian Constitution was Joaquim B. Barbosa Gomes. Gomes, who in May of 2003 was appointed by Brazilian President Luis Inácio Lula da Silva as the first black minister on the Supremo Tribunal Federal, the Brazilian Supreme Court, had been a federal prosecutor in Rio de Janeiro and an Adjunct Professor at the Faculty of Law at the State University of Rio de Janeiro."s Gomes, who received a doctorate in law from the University of Paris and who hed been a visiting professor at Columbia Law School in the United States, was a student of Brazilian Constitutional law and the nation's Supreme Court ${ }^{56}$ Gomes would bring a strong comparative perspective to the debate over law and racial remedy in Brazilian society. He began his article, Discriminaçâo Racial: Um Grande Desafio Para o Direito Brasileiro, ${ }^{57}$ critiquing Brazilian anti-discrimination law with a quotation from the Warren opinion in Brown:

[E]ducation is perhaps the most important function of state and local governments. Compulsory school attendance laws and the grest expenditures for echucation both demonstrate our recognition of the importance of educstion to our democratic society. It is required in the performance of our most basic public responsibilities, even service in the armed forees. It is the very foundation of good citizenship. Today it is a principal instrument in awakening the child to cultural values, in preparing him for later professional training, and in helping him to adjust normally to his environment. In these

54. Sec, for example, Braxilian legal scholar Hedio Silva's discusecion of affirma tive action and the 1988 Constiation. Hédio Silva Jr. A sao Affirmativa Na Constifuiçáo de 1988, in Aça Afrirma Jiva $\mathrm{E}$ Diversddade No Trabalho, supra note 53. In this article, Silva argues that the anti-discrimination principles in the 1988 Constitution should not be seen as posing a bar to affimative sction. Id. Instead, Silva argues that the state should be able to take into account societal reafitiea and take positive action to promote equality. Id.

55. Gomes' appointment to the Supremo Tribumal Foderal (STF) gamerod a significant amount of media attention in Bracil. Ho was noted as the first black STF Minister. A number of observers have noted that thero wero previous ministers with some African ancestry. It should be noted that in Brazil sharp distinctions are often made between those who are designstod "preso," or black, and those who are designated "pardo," or mulatto. There has been a movement in recent years calling upon all people of African descent to use either the term "negro," or Negro, or "afrodescondente," or Afro-descended, as a way of fostering unity among peoples of Africen descent acrose color lines.

56. See JoAqum B. Barbosa Gomes, La Cour Supreme Dans Le Systeme Polmour Bresilien (1994).

57. Joequim B. Durbosa Gomes, Discriminaçdo Radal: Um Grande Desafio Pare o Direito Brasileiro, at htt:/hww.infojus.com.br/area3/janquimbarbosa.htm (last visited Nov, 23, 2004). 
days, it is doubtful that any child may reasonably be expected to succed in life if he is denied the opportunity of an education. Such an opportunity, where the state has undertaken to provide it, is a right which must be made available to all on equal terms."

Gomes' use of the Warren opinion was part of his broader call for Brazilian courts to employ a more realistic and less formalistic jurisprudence, especially in dealing with the issue of racial inequality. The quoted Warren language, and indeed the Brown case more generally, employed the language and logic of legal realism, looking toward social impact and public policy as much as formal legal doctrine. ${ }^{39}$ Gomes argued that the Brazilian legal system needed to take into account social reality in determining the issue of affirmative action in education:

But education is precisely a perfect example of the divore between bw and reality.... On the eve of the turn of the millennium, ... the schools that offer good quality instruction in Brazil are, in general private schools. Despite being private these schools receive various types of government financtug, including a form of direct aid for construction and repair of their facilities and through financial exemptions of various kinds. Only those families blessed with considerable financial resources bave the means to enroll their children in private schools. Negroes therefore are excluded from this system by reason of the unjust entifices created by this very law."

Gomes then discussed the problem of inequality in university admissions:

The injustice becomes still more intolerable when we consider university education. Here the equation is inverted: the good universities are public. Contrary to what occurs in the United States where there is a great diversity of institutions of higher learning, in Brazil good quality university instruction is confined to public universities. Very few private universitics offer education of reasonable quality. Nevertheless access to the public university is extremely limited: the selection of students is made through the vestibular exam Those who pass, particularly for the courses with higher prestige, are overwhehmingly students from private schools, who bosides having bod the privilege of attending good schools, indiroctly financed with public resources . . . are also given financial resources to attend epecial preparatory courses for the vestibular."

Gomes went on to criticize the Brazilian educational system as one where tax dollars were channeled to subsidize an elite education for the rich and to

58. Brown v. Bd of Educ., 347 U.S. 483,493 (1954).

59. See, eg. Willium E Nelcon, Chlldress Lecture: Brown v. Board of Education and the Jurisprudence of Legal Reallsm, 48 ST. Lours U. LJ. 795 (2004). Oomes alco extersively quoted Italian jurist Mauro Cappelletti, who arguod that lew had to be responsive to social conditions. See GoMes, supra nole 56.

60. See GoMes, supra note 56 (Robert J. Cottrol trans.).

61. Id. (Robert J. Cottrol trans.). 
perpetuate a vicious cycle of misery and exclusion for the poor ${ }^{62}$ He urged lawyers and judges in Brazil to look to the example of civil rights policy in the United States. According to Gomes, both Brazil and the United States had managed to effectively exclude people of African descent from the mainstream of society. Gomes noted that in the United States, this was accomplished through formal law, citing Plessy v. Ferguson as an illustration; in Brazil, exclusion was accomplished through informal mechanisms. ${ }^{63}$ Additionally, Gomes noted that, since the 1960s, the United States had forthrightly come forward with a program of civil rights law and policy designed to combat discrimination. Gomes also commended affirmative action programs in American universities. ${ }^{64}$ Gomes' argument in favor of affirmative action was based on his reading of the parallel histories of slavery and post-emancipation marginalization in Brazil and the United States and the relatively greater success of the American civil rights effort since the 1960 s. It was also influenced by French legal norms and the notion of "positive discrimination" or "positive action" that has developed in French law. . $^{35}$

Other legal scholars have also argued for a more flexible approach to the issue of equality and affirmative action. Hédio Silva Jr., in his discussion of affirmative action and the 1988 Constitution, called for a recognition of a distinction between discrimination that produces inequality and a discrimination that compensates for structural or existing inequality. ${ }^{66}$

Writings by legal scholars like Gomes and Silva bolstered the opinions of those who argued that the post-1960s American civil rights experience had lessons for those concerned with race and inequality in Brazil. By 2001, tentative steps were being made toward affirmative action programs in governmental ministries and higher education. In that year, with the support of Bernadette da Silva, Rio de Janeiro's first Afro-Brazilian governor, the state legislature passed three statutes instituting a system of quotas for the

62. Id.

63. 'Id

64. Id.

65. Joaquim B. Bubosa Gomes, A Recepedo do Instivuto da Açdo Afirmativa Pelo Direito Constifucional Brasileiro, at htp:/tww adamiadv.br/artigos. asp (follow link to articlo) (last visited Sept. 15, 2004). Gomes cited French logal scholar V. Bernadette Renauld's discussion of positivo discrimination. See V. Bemadette Renauld, Les Discriminations Pasitives, 1997 Revus TRmastr menE Des Drorts De L'номмв 425. See also Josquim B. Barbosa Gomes, $O$ Debare Constitucbnal Sobre as Acoses Afirmatives, at http//www.mundojuridicosdv.br./documentos/artigos/texto028.doc (last visiled Sept. 15, 2004) (discussing the constitutionality of affinmative action and the world-wide adoption of affirmative action measures).

66. See Silva, supra note 54. 
state's two public universities, the State University of Rio de Janeiro and the University of North Fluminense. The legislation called for a quota of 50 percent for graduates of public schools, 40 percent for Afro-Brazilians and 10 percent for the physically disabled. ${ }^{67}$ Some other states also followed with affirmative action programs of their own. ${ }^{68}$

The program quickly came under intense criticism. Opponents argued that it violated anti-discrimination principles in the Brazilian constitution and that it was anti-meritocractic. ${ }^{69}$ Even champions of affirmative action like Joaquim B. Barbosa Gomes saw quotas as an extreme form of affirmative action that should only be employed to combat the most extreme and entrenched forms of inequality. ${ }^{\text {TO }}$ Supporters argued that the program was necessary in order to attack entrenched inequality in Brazilian life." One ironic feature of the Rio program was that because the program provided quotas for people of African descent, some whites were able to benefit from the program by claiming to have a remote black ancestor. ${ }^{2}$

The newly instituted affirmative action measures are being challenged in the Brazilian courts and face a potentially uncertain future. Arguments that are certainly familiar to students of the affirmative action debate in the United States are being advanced in Brazilian courts. These arguments, concerming stark inequalities of results, meritocracy in university admissions, the possibility of color-blind alternatives, and the possibilities of taking race into account in the face of anti-discrimination constitutional provisions, have become part of the Brazilian debate, as indeed they are clearly part of the debate in the United States.

The American experience with the modern civil rights movement-an experience Brown did much to precipitate and help shapo-contributed to the growth of the Brazilian struggle against racial inequality in several important ways. First, by taking the civil rights struggle beyond the mere breaking of

67. O Amicus Orriae e Apso Afrmativa na UERJ-A Nova Lel No. 4.151/2003, at http:/l whw edami.atv.br/artigos.2sp (lasted visited Sept. 15, 2004).

68. Recusen, supra note 29 , at 788.

69. Some Bravilian critics of affirmative action ergue against race-based affirmative acticen as violative of the equality principle in the 1988 Constitution and argue forstead for affirmative action based on class or socio-economic criteria. See, e.g., Rubens Cartaxo, Sistema de cotas, a melhor politica compensabsria?, at bitp:J/www.jus.com br (last visited Nov. 23, 2004).

70. See, e.g. Joaquiom B. Barbosa Gomes, dfirma que polltica de cotas nao é Única Solucalo, at htpp:/hww.mandojuridico.adv.tr/html/noticiastmaio046.htm.

71. See, e.8.. Wagner Camib, O Racimo e a Politica de Cotas Nas Untversidades, at http://www. mp.mt gov.br/ceaflajuridicos/ajur_13.esp (last visited Jan. 27, 2005).

72. Racusen, supra note $2 \overline{9}$, at 792 . 
caste or caste-like barriers, the American civil rights movement helped to demonstrate the limitations of formal egalitarianism. If the law had helped contribute to often-profound racial inequality in the United States, it was clear that mere legal change, the abolition of de jure segregation in schools, the lifting of Jim Crow laws, and even the passage of anti-discrimination legislation, were not going to undo the results of centuries of slavery and exclusion. Champions of a racially-egalitarian society realized that the effort would have to be taken even further. By the 1970s, having largely won the battle to dismantle formal discrimination in law, civil rights advocates in the United States increasingly tumed their attention to the law's actual impact. American law was becoming increasingly concerned with the question of whether or not the law, as a substantive matter, treated people of different races equally. For example, that concern came in the form of the Supreme Court's finding that some level of affirmative action in university admissions is constitutional, ${ }^{73}$ or the Court's creation of a body of law in the field of employment discrimination that allowed discrimination to be inferred from statistical, rather than direct, evidence. ${ }^{74}$

This concern led to a second American contribution to Brazilian civil rights discourse. Critics of Brazilian jurispnudence have stressed the formalistic nature of Brazilian judicial reasoning. ${ }^{75}$ Brazilian supporters of affirmative action have contrasted this formalism with the flexibility of the U.S. common law system and how that flexibility has allowed both the executive branch and the courts to accommodate a system of affirmative action that takes into account social and economic disparities in American life. ${ }^{76}$ Some Brazilian scholars have also noted how American courts have managed to find the constitutional space to permit affirmative action, while also ruling that quotas violate the equal protection principle." This latter point may become particularly important as the quotas adopted at the state universities of Rio de Janeiro and other institutions come under constitutional challenge. In my view, Brazilian legal scholars, such as Gomes and Menezes, among others, may be trying to carve out a constitutional space that would allow public institutions in Brazil to take race into account, even if they do not

73. Regents of the Univ. of Cal. v. Bakke, 438 U.S. 265 (1978).

74. For a good methodological discussion of the use of statistical evidence in employment discrimination cases, see Joseph L. Gastwinth, Issues Arising in the Use of Statistioal Evidence in Discrinimalion Cares, in Statistical Science in the CoUrTroom 227 (Joeph L. Gastwirth ed., 2000).

75. See, ag., Puulo lncera de Medezes, a Acho Aftrmatrva (Afpirmatrve Action) No Diretro Norte-AmerJCANo 33 (2001).

76. Id.

77. Id. 
employ the kind of rigid quotas that bave developed in some public institutions in Brazil. In short, Brazilian advocates of affirmative action were arguing for the importation of the kind of legal realism that has long been influential in American jurisprudence, was critical in the development of American civil rights law, and played a critical part in the Brown decision. ${ }^{78}$

Brazilian legal scholars, social scientists, and civil rights activists are looking to the U.S. experience, and the experience of other nations, in an effort to find ways that law might be employed in the service of breaking down structural inequalities, or at the very least ensuring that the law does not hinder such efforts. There are lessons that we in turn in the United States should draw from this experience. Probably foremost among these is the realization that the elimination of a formal legal caste system, the lind that Thurgood Marshall, Jack Greenberg, Constance Motley, Robert Carter, Spottswood Robinson, and others struggled against in Brown v. Board of Education, is really only the beginning, and not the end, of the effort to eradicate entrenched, structural inequality. We see, if we look closely at the Brazilian experience, a nation that has long had egalitarian constitutional norms. Indeed, one might even claim that for free Afro-Brazilians, formal equality before the law even pre-dated the general emancipation of $1888 .^{79}$ And yet, despite the early achievement of de jure egalitarianism in Brazilian life, deep, racially-related inequalities persist in Brazilian society. This can, if we let it, be an important cautionary lesson for those in our society who might be seduced into believing that formal equality before the law is all that is required to achieve racial justice.

But, even more broadly, I would hope that our current celebrations and reflections on Brown v. Board of Education would cause us to ask broader, comparative questions concerning law and inequality. Brown was part of a world-wide effort to tear down traditional barriers that deemed some people superior and others inferior simply by the accidents of their births. It was, I think, the most prominent judicial manifestation of this effort. By looking at Brown in a comparative context as part of a larger world-wide effort to tear down walls of caste and race, we can get a more complete picture of the true importance of the 1954 school desegregation decision. It changed America. But it was also a stone thrown into a much larger pond. Its ripples have not yet stopped.

79. See Cottrol, supra note 21, at 56-57. See also supra note 31 and accompanying text. 